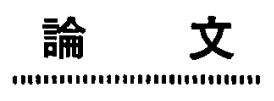

\title{
石油炭化水素から芳香族炭化水素の生成 (2) 触媒酸性度と芳香族化選択性についで
}

\author{
吉田 浩**, 冨田 裕**, 冨士原 広**, 鈴 村 基**
}

The Formation of Aromatics from Petroleum Hydrocarbons (2)

On the Acidity and the Aromatization Selectivity of the Catalysts*

by Hiroshi Yoshida**, Yutaka Tomita**, Hiroshi Fujiwara** and Hajime Suzumura**

Summary : A correlation between the surface acidity and the aromatization selectivity of the chromiaalumina and molybdena-alumina catalysts has been investigated.

The acid sites existing on the surface not only on the alumina, but also on the chromia (or on the molybdena) work as a catalyzer to induce the side reactions such as carbonaceous deposition, cracking and so on, which tend to lower the selectivity of the aromatization of $n$-heptane.

The addition of alkali metal ions or alkaline earth metal ions to these catalysts neutralizes the acid sites, thereby suppressing the side reactions and hence increasing the dehydrocyclization selectivity.

Alkali metal ions were more effective promoters per ion than alkaline earth metal ions, and, in general, larger metal ions were observed to have a greater promotional effect than smaller ions among the same group on the aromatization selectivity.

The aromatization selectivity of the catalyst increased as the surface acidity decreased.

\section{1 赭言}

クロミアーアルミナ触媒は脱水素反応および脱水素環化反応 にばかりでなく，他の反応にも広範囲に使用されているため数 多くの研究がなされている。触媒の物性の面からの研究として は, Selwood, Eischens ${ }^{2}$ による磁化率ならびに X 線回折に よるクロミアーアルミナ触媒の表面状的の研究, Cossee, Van Reijen $^{3)}$ による ESR による同様な研究, Owen") の触媒表面 皘と脱水素活性の関俰についての研究, Weisz, Prater, Rittenhouse $ら^{\text {() }}$ の触媒の電尊度と脱水素活性についての研究， Voltz, Weller ${ }^{()}$およひ Gremillion, Knox ら"のクロミアーア ルミナの表面酸化状態に関する研究などがある。一方，モリブ デナーアルミナ触媒に関しての物性の面での研究は数少なく， Russel, Stokes ら ${ }^{\text {) }}$ による触媒表面積と活性および熱安定性に 関する研究，Webb, Smith, Ehrhardt ら”の電子顕微鏡によ る佸性状態の研究などがある。

筆者らはクロミアーアルミナ拉よびモリブデナーアルミナ触媒 の表面酸性度がパラフィンの芳香族化反応に与える影警につい て夷験を行なった。パラフィンの芳香族化反応伤しては，主 反応の脱水素㻴化反応のほかに分解, 炭素梊化,異性化,不均化 などの反応が併発する。このことから考えて,これら触媒上には いわゆる“酸性点”が存在することが容易に推察される゙"。こ れらの副反応を抑制して主反応の選択性を向上させるためにア

*昭和 40 年 5 月 17 日受理

** 八幡化学工業株式会社 東京研究所 (川猗市井田)

Tokyo Laboratory of Research Center, Yawata Chemical Industry Co., Ltd. (Ida, Kawasaki)
ルカリ金属，またはアルカリ土類金属を添加する試みがなされ ているが(1) 17)，これら金属の添加による触媒酸性度の変化と 芳香族化反応選択性との間の相関性についての研究注ほとんど 報告されていない。そこで筆者らは，触媒担体( $r$ ーアルミナ)お よび触媒（クロミアーアルミナおよびモリブデナーアルミナ）の 酸性度と $n$-ヘプタンの芳香族化反応における選択性の関係な らびにこれらの触媒に対するアルカリ金属, アルカリ土類金属 の添加効果について実験した結果を報告する。

なお触媒表面の酸性度の測定法に関しては各種提案されてい るが(10),18)，19)，反応条件に近い条件下で測定できるといら利点 のある気相塩基吸着法 ${ }^{20}$ をを用いた。

\section{2 実 験 法}

\section{1 実験装置および操作}

\section{1 .1 触媒酸性度の湘定法}

塩基としてピリジンを選択した。理由は湘定条件下で安定な ことと，分子の大きさが芳香族化反応により生成するベンゼン 環の大きさに近いことからである。

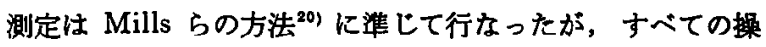
作を水素気流中で行なった点のみが異なる。すなかちがラス製 バスケットの中に試料(あらかじ空気中で $500^{\circ} \mathrm{C} て ゙ 2$ 時間焼 成したもの) 10〜15 g 入れ，ガラス製ロッドで分析用直示 天びんに連結し重量変化を直接測定する。試料を水素気流中で 約 40 分を要して $500^{\circ} \mathrm{C}$ まで上げ 30 分間この温度に保ち吸着 測定開始前に $300^{\circ} \mathrm{C}$ に温度を下げ試料の重量が恒量になって 
いることを確かめてからピリジン蚫和器を通した水素を 120 $\mathrm{ml} / \mathrm{min}$ の流速で㝵入して, $300^{\circ} \mathrm{C}$ におけるビリジン蒸気の吸 着量を測定する。吸着を 100 分続けるとほぼ平衡状態となるの でピリジンの腥入を止めて，水案のみを $120 \mathrm{ml} / \mathrm{min}$ の流速で 通して物理吸着分のピリジンを脱着させる。脱着時間はすべて 200 分とした。ピリジンは市販特級品を酸化バリウムの存在下 に蒸留して水分を除いてからカセイカリ上で眝えたものを用 い, 水素はボンべ水素（純度 99.99\%) をDeoxo 装固, シリ カゲルカラム、モレキュラーシーブ3A カラムに順次通したも のを用いた。なお吸着装固を出てトラップされた油には着色は なく，ガスクロマトグラフィー分析ではピリジン以外の成分は 検出されなかったので，この測定条件ではピリジンの分解，水 添等の反応は起らなかったと考える。

\subsection{2 媒表面棈，細孔分布等の测定法 ${ }^{21}$}

䖵媒の比表面積は Nelsen, Eggertsen ら ${ }^{22)}$ が提案したガス クロマトグラフィーを用いる方法により，また細孔分布，全細 孔容糟，平均細孔直径は Haley ${ }^{23}$ が考案した方法で測定し， BJH 法"1)により計算した。

\section{1 .3 劳香族化反応実験}

䖵媒の芳香族化反応に対する活性試験には，原料上してn一へ プタン (Phillips 社 Pure Grade, 純度 $99.5 \mathrm{~mol}$ 以上) を用 いた。装置は第 1 報 ${ }^{23)}$ に記载したbのと同一である。すなわち 内经 $25 \mathrm{~mm} \phi$ の石英製反応管に触媒 $40 \mathrm{ml}$ を充テンした常圧 流通式装㯰である。操作ならびに生成物の分析法も第 1 報のと おりである。

以下に記載する反応結果は特にことわらない限りは，反応開 始後 60〜120 分の 1 時間の成縝で示した。

\section{2 䖪媒調製法}

触媒はすへて含浸法 (Impregnation 法) により調製し，用 レた試薬はすべて市販特級品である。

クロミアーフルミナ触媒 (13.8 wt\% $\mathrm{Cr}_{2} \mathrm{O}_{3}-86.2 \mathrm{Al}_{2} \mathrm{O}_{3}$ )

$500^{\circ} \mathrm{C}$ で 2 時間空気中で狫成した担体アルミナを所定量容器 に探り，湯浴上で 1 時間真空ポンプで吸引して細孔中の気ホウ を除いた後に所定量の無水クロム酸水溶液（ちょ5ど含浸させ るのに十分な量）を商下してアルミナに含浸させる。そのまま 1 時間放置後湯浴上で減圧乾嬠し,ついで空気中で $500^{\circ} \mathrm{C}, 2$ 時間焼成した。

助触媒付きクロミアーアルミナ触媒

上記のクロミアーアルミナ触媒に同じ方法で所定量のアルカ リ金属またはフルカリ土類金属の硝酸塩の水溶液を含浸させ, 乾燥後再ひ空気中で $500^{\circ} \mathrm{C} 2$ 时間焼成した。
モリブデナーフルミナ触媒 (10 wt96 $\left.\mathrm{MoO}_{3}-90 \mathrm{Al}_{8} \mathrm{O}_{8}\right)$

所定量のモリブテン酸アンモニウム $\left(\left(\mathrm{NH}_{4}\right)_{6} \mathrm{MO}_{7} \mathrm{O}_{24} \cdot 4 \mathrm{H}_{2} \mathrm{O}\right)$ 水溶液を上記触媒と同様にアルミナに含浸させて乾燥, 烧成し たものである。

\section{助触煤付きモリブデナーアルミナ触媒}

上記のモリブデナーアルミナ触媒に，同様な方法により所定 最のアルカリまたはアルカリ土類金属硝酸塩の水溶液を含浸さ せて乾燥，焼成した。

これらの触媒はいずれも反応開始前に水秦気流中で $500^{\circ} \mathrm{C} 2$ 時間邆元してから反応を行なった。

\section{3 実験結果および考察}

3.1 クロミアーアルミナ触媒における担体アルミナの影褰

アルミナはそれ自身に固有酸性度があり，その酸性度, 酸強 度分布は調製法，乾燥条件などにより異なることが知られて いる20)。また翼なった酸性度を有するアルミナを担体として用 いたクロミアーアルミナ"27およびモリブデナーアルミナ触媒 ${ }^{28)}$ 上 での各種炭化水素の反応も報告されている。笔者らは 6 種の市 販アルミナ担体を使用してクロミアーアルミナ触媒を調製し， それらの酸性度と $n$-ヘプタンの芳香族化選択性, 炭素啠析出量 等の間の関倸につき検討した。表 1 に使用した担体アルミナの 性状について，また表 2 にこれらの担体を使用したクロミアー アルミナ触媒の酸性度と芳香族化反応の結果を示した。ピリシ ン吸着量から求めた 6 種のアルミナの単位表面積めたりの酸性 点の数（一つの酸性点に対して一つの分子が吸着すると仮定し て)は 1.3 2.8 $10^{21}$ sites $/ \mathrm{cm}^{2}$ となり, Pines, Haag ら ${ }^{26)} の$ トリエチルアミンの気相吸着よりの測定值 $0.3 \sim 2.6 \times 10^{13}$ と 良く一致しているが，アンモニア化学吸着法 ${ }^{29)}\left(1 \times 10^{14}\right)$ ， シ オキサン滴定法 ${ }^{80)}\left(2 \times 10^{20}\right)$ の值よりはかなり小さい。この理 由は明らかでないが用いた化合物の塩基性の相異と立体的な要 因が関与していると思われる。

酸性度の異なったアルミナ担体にそれぞれ 13.8 wt\%の $\mathrm{Cr}_{2} \mathrm{O}_{2}$ を担持させた触媒の酸性度は 0.016 0.033 Meq/g の䇤 囲で元の担体より増加し, 表 2 からかかるよ5にその順序は担 体のそれとよく一致している。このことはクロミア側にも酸性 点があることを示している。ちなみに無水ク口ム酸を他の触媒 と同一条件で焼成して調製した $\mathrm{Cr}_{2} \mathrm{O}_{3}$ の酸性度は $0.049 \mathrm{Meq} / \mathrm{g}$ であった。

$500^{\circ} \mathrm{C}$ における $n$-ヘプタンからの芳香族収率，選択率はと もに表 2 に示すごとく酸性度の增加とともに減少し，炭素所析 出量は逆に增大している。このことは酸性度の大きい触媒は小

表1 担体了ルミナの性状

\begin{tabular}{|c|c|c|c|c|c|c|c|}
\hline 担体フルミナ・ & 此表面 & $\begin{array}{c}\text { 全細孔容種 } \\
(\mathrm{m} / / \mathbf{g})\end{array}$ & $\begin{array}{c}\text { 平均細孔直径 } \\
\text { (A) }\end{array}$ & 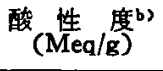 & $\underset{(w+\%)}{\mathrm{SiO}_{2} \text { 含有 }}$ & 形 & 状 \\
\hline A (フメリカA社) & 253 & 0.152 & 30 & 0.056 & 0.26 & $8 \sim 10 \times ッ シ=$ & 粒状 \\
\hline$B$ (同上) & 203 & 0.259 & 51 & 0.083 & 0.04 & $1 / 8$ in & 球状 \\
\hline C (国 内 A 社) & 205 & 0.260 & 53 & 0.089 & 0.10 & $8 \sim 10$ メッシン & 球状 \\
\hline$D$ (国 内 B 杜) & 261 & 0.326 & 59 & 0.096 & 8.0 & $8 \sim 10 \times ッ シ ュ$ & 球状 \\
\hline$E$ (フメリカA社) & 366 & 0.322 & 39 & 0.110 & 5.2 & $1 / 8$ in & 球状 \\
\hline F (国 内 B 社) & 279 & 0.347 & 57 & 0.129 & 8.2. & $8 \sim 10 \times ッ シ=$ & 球状 \\
\hline
\end{tabular}

注：a）試料はすべて $500^{\circ} \mathrm{C} ， 2$ 時間，空気中で焼成したすの。

b) $300^{\circ} \mathrm{C}$ におけるビリジンの化学旪着量として求めた。 $\mathrm{Meq} / \mathrm{g}$ は mol/g と同し。 


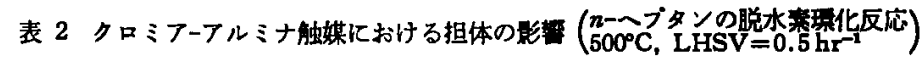

\begin{tabular}{|c|c|c|c|c|c|c|c|c|}
\hline 触 & 酸 & $\begin{array}{l}\text { 対原料液収率 } \\
\text { (wt\%) }\end{array}$ & $\begin{array}{l}\text { 䘸中芳香方 } \\
\text { (wt }\end{array}$ & 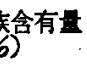 & $\begin{array}{l}\text { 全芳香族收率 } \\
\text { (mol\%) }\end{array}$ & $\begin{array}{c}\text { 全芳香族選択率 } \\
(\text { mol\%) }\end{array}$ & 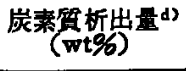 & $\begin{array}{l}\text { 生成ガス量 } \\
\left(l_{\text {NTP }}\right)\end{array}$ \\
\hline $\begin{array}{l}13.8 \mathrm{wt} \\
\mathrm{Cr}_{2} \mathrm{O}_{2}-\mathrm{Al}_{2} \mathrm{O}_{3} \text { (A) }\end{array}$ & 0.089 & 85.0 & $\begin{array}{r}\left.1.7^{\circ}\right) \\
55.5^{\circ)} \\
\left.0.1^{\circ}\right)\end{array}$ & 57.3 & 53.1 & 78.0 & 1.92 & 7.32 \\
\hline " $-\mathrm{Al}_{2} \mathrm{O}_{3}(\mathrm{~B})$ & 0.112 & 82.3 & $\begin{array}{r}1.5 \\
44.1 \\
0.2\end{array}$ & 45.8 & 41.1 & 68.7 & 2.26 & 6.37 \\
\hline - $-\mathrm{Al}_{2} \mathrm{O}_{4}(\mathrm{C})$ & 0.116 & 80.6 & $\begin{array}{r}1.6 \\
42.4 \\
0.3\end{array}$ & 44.3 & 35.3 & 61.1 & 3.95 & 6.58 \\
\hline - $-\mathrm{Al}_{2} \mathrm{O}_{3}(\mathrm{D})$ & 0.121 & 75.8 & $\begin{array}{r}2.2 \\
41.4 \\
0.3\end{array}$ & 43.9 & 36.5 & 60.1 & 4.25 & 7.15 \\
\hline - $-\mathrm{Al}_{2} \mathrm{O}_{3}(\mathrm{E})$ & 0.126 & 82.5 & $\begin{array}{r}1.2 \\
32.8 \\
0.2\end{array}$ & 34.2 & 30.8 & 62.5 & 2.20 & 4.86 \\
\hline " $-\mathrm{Al}_{\mathbf{2}} \mathrm{O}_{6}(\mathrm{~F})$ & 0.159 & 77.5 & $\begin{array}{r}1.8 \\
31.1 \\
0.3\end{array}$ & 33.2 & 28.2 & 54.2 & 6.13 & 5.93 \\
\hline
\end{tabular}

注：a） ベンゼン

b) トルエン

c) キシレン

d）炭秦質析出量は反応前後の触媒重量の差から求めた。対原料 wt \% である。

e） $\mathrm{Cr}_{1} \mathrm{O}_{2}$ (無水ク口A酸を㜔成したもの) の酸性度は $0.049 \mathrm{Meq} / \mathrm{g}$ であった。

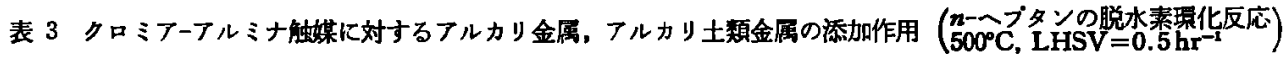

\begin{tabular}{|c|c|c|c|c|c|c|c|c|}
\hline 触 & 酸 & $\begin{array}{c}\text { 対原料液収率 } \\
(\mathrm{wt} \%)\end{array}$ & $\begin{array}{r}\text { 液中芳香 } b \\
(\mathrm{wt})\end{array}$ & 念有是 & $\begin{array}{c}\text { 全芳香族收蚶 } \\
\text { (mol\%) }\end{array}$ & $\begin{array}{c}\text { 全芳香族巽択事 } \\
(\mathrm{mol} \%)\end{array}$ & $\begin{array}{c}\text { 炭素筫析出量 } \\
(\mathbf{w t} \%)\end{array}$ & 生盛ガス \\
\hline $13.8 \mathrm{wt} \% \mathrm{Cr}_{2} \mathrm{O}_{8}-\mathrm{Al}_{2} \mathrm{O}_{2}$ & 0.116 & 80.6 & $\begin{array}{r}1.6^{(3)} \\
42.4^{d)} \\
0.3^{\circ 3} \\
\end{array}$ & 44.3 & 39.0 & 61.5 & 3.95 & 6.58 \\
\hline $\mathrm{K}_{2} \mathrm{O}-\mathrm{C}_{T_{2}}\left(\mathrm{O}_{\mathbf{3}}-\mathrm{Al}_{\mathbf{2}} \mathrm{O}_{\mathbf{1}}\right.$ & 0.071 & 84.6 & $\begin{array}{r}1.8 \\
63.7 \\
-\end{array}$ & 65.5 & 60.8 & 79.6 & 1.38 & 8.43 \\
\hline $\mathrm{K}_{2} \mathrm{O}-\left(\mathrm{K}: \mathrm{Cr}_{\mathrm{r}}=2: 10\right)$ & 0.048 & 84.2 & 70.1 & 72.2 & 66.3 & 83.8 & 0.33 & 8.93 \\
\hline $\mathrm{K}, \mathrm{O},(\mathrm{K}: \mathrm{Cr}=4: 10)$ & 0.040 & 85.8 & $\begin{array}{r}3.9 \\
78.6 \\
-\end{array}$ & 82.5 & 77.2 & 88.3 & 0.42 & 10.51 \\
\hline $\mathrm{K}, \mathrm{O},(\mathrm{K}: \mathrm{Cr}=6: 10)$ & 0.047 & 81.9 & $\begin{array}{r}3.7 \\
61.4 \\
-\end{array}$ & 65.1 & 58.5 & 80.4 & 0.24 & 8.41 \\
\hline $\mathrm{Li}_{2} \mathrm{O}$ & 0.095 & 80.3 & $\begin{array}{r}1.7 \\
45.2 \\
\end{array}$ & 46.9 & 41.1 & 65.3 & 2.04 & 6.27 \\
\hline $\mathrm{Na}_{2} \mathrm{O}-(\mathrm{Na}: \mathrm{Cr}=2: 10)$ & 0.069 & 83.0 & $\begin{array}{r}1.7 \\
64.2\end{array}$ & 65.9 & 59.6 & 78.6 & 0.90 & $8: 49$ \\
\hline $\mathrm{Cs}_{2} \mathrm{O}-\left(\mathrm{Cs}_{\mathrm{s}}: \mathrm{Cr}_{\mathrm{r}}=2: 10\right)$ & 0.050 & 82.8 & $\begin{array}{r}2.5 \\
61.2 \\
\end{array}$ & 63.7 & 57.7 & 78.9 & 1.05 & 8.22 \\
\hline $\mathrm{MgO}\left(\mathrm{Mg}_{\mathrm{g}}: \mathrm{Cr}=2: 10\right)$ & 0.107 & 81.6 & $\begin{array}{r}1.5 \\
42.6 \\
-\end{array}$ & 44.1 & 39.4 & 63.7 & 2.59 & 6.57 \\
\hline $\mathrm{CaO},(\mathrm{Ca}: \mathrm{Cr}=2: 10)$ & 0.115 & 82.2 & $\begin{array}{r}1.5 \\
63.4 \\
-\end{array}$ & 64.9 & 58.2 & 77.2 & 1.83 & 8.27 \\
\hline $\mathrm{BaO},(\mathrm{Ba}: \mathrm{Cr}=2: 10)$ & 0.091 & 82.9 & $\begin{array}{r}1.6 \\
42.8 \\
-\end{array}$ & 44.4 & 39.9 & 66.4 & 2.17 & 6.45 \\
\hline
\end{tabular}

注：a）ここK用いた触媒はすべて同一パッチの $13.8 \mathrm{wt} \% \mathrm{Cr}_{3} \mathrm{O}_{8}-86.2 \% \mathrm{Al}_{3} \mathrm{O}$ （担体はC）から含浸法により調製したもので，すべて硝酸塩を 含浸させ, $500^{\circ} \mathrm{C}, 2 \mathrm{hr}$ 空気中で焼成した。

b) 原子比

c) ジンゼン, d) トルエン, e) キシレン

さい強媒よりも酸性点の関与する副反応を起しやすいことを示 している。

3.2 クロミアーアルミナ触媒に対するアルカリおよひアルカ リ土類の添加効果

3.1 でクロミアーアルミナ触媒上には担体アルミナ側のみで なくクロミア側にも酸性点が存在することを示した。これら
の酸性点の関与する副反応を抑えることにより主反応である脱 水素罢化反応の選択性を向上し，かつ触媒寿命も長くできるこ とが推察される。

そこでクロミアーアルミナ触媒に対するアルカリおよびアル カリ土類の添加による酸性度の変化と芳香族化反応に対する影 響について実鏂した。表 3，図 1，2 に示すよ5に触媒酸性度は 


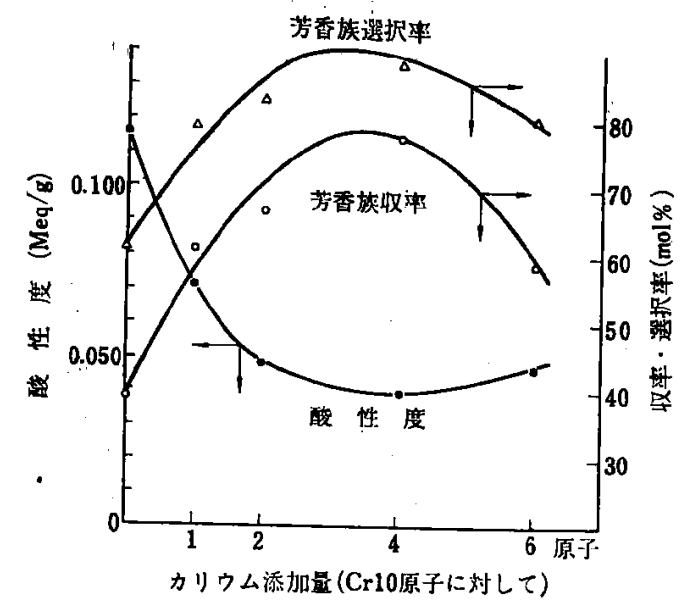

因 1 クロミフーフルミナ螌某に対するカリウムの添加作用

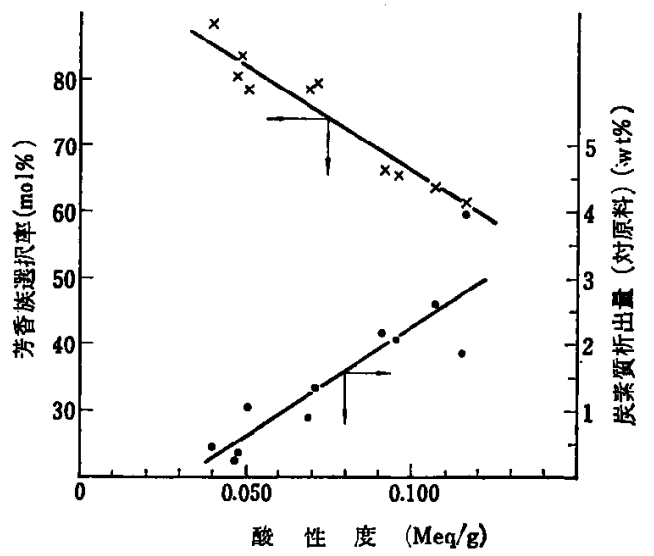

因 2 クロミフーフルミナ系触媒の酸性度と芳香族化反応 （表3ょりブロット）

カリウムの添加量の増加とともに減少するが，添加量が多くな る場合には逆にわずかではあるが上昇する傾向がみられる。芳 香族収率および選択率は酸性度の変化とよく対応し酸性度の娍 少につれて上㫒するがカリウム添加量が多い場合には逆に低下 ナる。この原因としては過剩のカリウムが後記するようにク口 ミアと重クロム酸カリウムのごとき化合物を形成すること，ク ロミア表面の脱水素活性点を物理的にプロックすること,ク口
ミアのシンタリン

グやクラスター化

を誘起する゙7こと

などが考えられ

る。また、カリウ

么添加量が多い場

合には図 3 に示す

よ5に反応開始後

に活性の上界がみ

られるが、これ

は Voltz, Weller

ら"3,16)加推测して

いるように触媒焼

成時の触媒上でク

ロム酸カリウムま

たは重クロム酸力

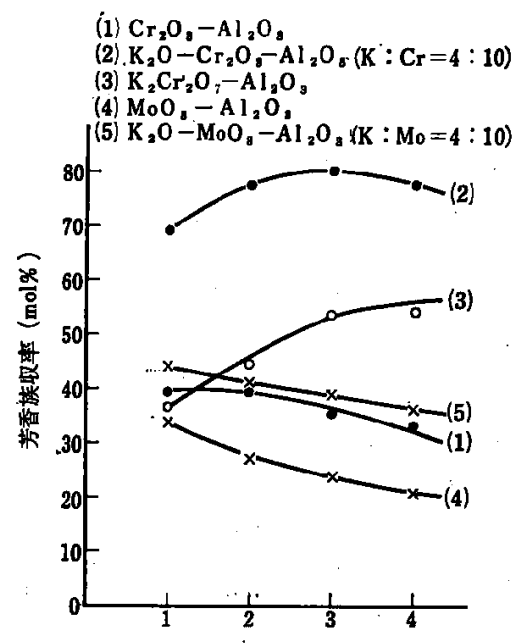

反店 時 間( $(\mathrm{hr})$

因 3 触媒活性の経時变化

リウムが形成されて還元されにくくなっていることが原因とし て考えられる。そこでアルミナ担体に $\mathrm{K}_{2} \mathrm{CrO}_{4}$ または $\mathrm{K}_{2} \mathrm{Cr}_{2} \mathrm{O}_{7}$ を添加した触媒 $\left(\mathrm{Cr}_{2} \mathrm{O}_{3}\right.$ として $13.8 \mathrm{wt} \%$ 添加した) を他の 触媒と同一条件で反応に用いたところ, 表 4, 図 3 に示すよう に $\mathrm{K}_{2} \mathrm{CrO}_{4}-\mathrm{Al}_{2} \mathrm{O}_{3}$ ではほとんど活性はないが, $\mathrm{K}_{2} \mathrm{Cr}_{2} \mathrm{O}_{7}-\mathrm{Al}_{2} \mathrm{O}_{3}$ ではかなりの活性があり，かつ経時活性上年が大きく、これは クロミアーフルミナにカリウムを多量に付けた触媒の場合と傾 向がよく似ている。このことより過剩のカリウムが触媒上で重 クロム酸カリウムのごときものを形成していると考えられる。 カリウムの添加方法としては表 4 に示すよ5に, アルミナ担体 に硝酸カリウムを含浸させて㛙成した後にクロミアを担持させ た触媒では, 芳香族化活性, 選択性は改良されるが, その添加 効果はクロミアーアルミナにあとから硝酸カリウムを源加した 場合よりも劣っている。このことより触媒の芳香族化選択性を 向上させるためには担体アルミナばかりでなくクロミアの酸性 点をも抑えなりればならないことがわかる。触媒上への炭素質 析出量は図 2 に示寸ように酸性度とよく対応している。酸性点 で生成した炭素啠はクロミア.上の脱水秦活性点を覆ったり触媒 細孔を閉ソクしたりして活性低下の原因となるが，アルカリの 添加により上の現象が抑えられるため芳香族化選択率のみなら

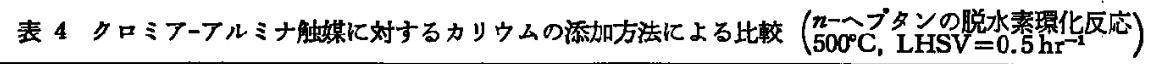

\begin{tabular}{|c|c|c|c|c|c|c|c|}
\hline 媒") & 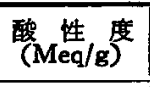 & $\begin{array}{l}\text { 対原料液収辛 } \\
(\text { wt } \%)\end{array}$ & $\begin{array}{c}\text { 液中若香族含有量 } \\
(\mathrm{wt} \%)\end{array}$ & $\begin{array}{l}\text { 全芳香族收案 } \\
(\mathrm{mol} \%)\end{array}$ & $\begin{array}{c}\text { 全芳白族選択率 } \\
\text { (mol\%) }\end{array}$ & 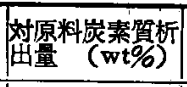 & 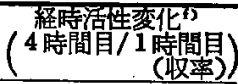 \\
\hline $\begin{array}{l}13.8 w t \% \\
\mathrm{Cr}_{2} \mathrm{O}_{3}-\mathrm{Al}_{2} \mathrm{O}_{2}\end{array}$ & 0.116 & 80.6 & 44.3 & 39.0 & 61.5 & 3.95 & 0.86 \\
\hline $\begin{array}{r}\left(\mathrm{K}: \mathrm{Cr}_{2}=2: 10\right) \\
\mathrm{K}_{4} \mathrm{O}-\left(\mathrm{Cr}_{2} \mathrm{O}_{8}-\mathrm{Al}_{2} \mathrm{O}_{3}\right)^{\mathrm{b})}\end{array}$ & 0.048 & 84.2 & 72.2 & 66.3 & 83.8 & 0.33 & 1.07 \\
\hline $\begin{array}{r}(\mathrm{K}: \mathrm{Cr}=2: 10) \\
\mathrm{Cr}_{2} \mathrm{O}_{2}-\left(\mathrm{K}_{2} \mathrm{O}-\mathrm{Al}_{2} \mathrm{O}_{3}\right)^{\mathrm{C}}\end{array}$ & 0.069 & 83.5 & 67.7 & 61.6 & 80.3 & 1.12 & 0.92 \\
\hline 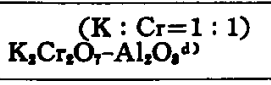 & 0.045 & 83.8 & 48.6 & 44.7 & 74.7 & 0.36 & 1.50 \\
\hline 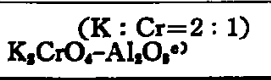 & 0.040 & 83.6 & 7.2 & 7.4 & 40.4 & 0.15 & 1.45 \\
\hline
\end{tabular}

注：a）担体てルミナはC。

b）クロミフーフルミナに弰酸カリウムを添加してから焼成した。

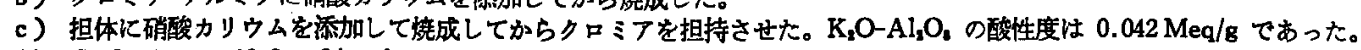

d) $\mathrm{Cr}_{2} \mathrm{O}$ として $13.8 \mathrm{wt} \%$ になるようK $\mathrm{K}_{2} \mathrm{C}_{\mathrm{I}_{2}} \mathrm{O}_{7}$ を添加した。

e ) $\mathrm{Cr}_{2} \mathrm{O}$, として 13.8 wt\% になるように $\mathrm{K}_{2} \mathrm{CrO}$ 、を添加した。

f） 1 時間目に対する 4 時間目の芳香族收率を示した。 
ず収率をも向上 させているもの と考えられる。 図 4 に反応前後 の触媒の細孔分 布を示したが， 反応後の触媒の 細孔 (ことに径 の小さなもの) は炭素質の析出 により一部閉y クされている がカリウムを 添加した触媒で は閉ソクが抑制 されていること がわかる。カリ ウム以外のアル カリ，アルカリ 土類でも表 3 , 图 5 に示すごと く同様な添加勏 果を持っている が，その芳香族 化通択性の向上 に対する効果の
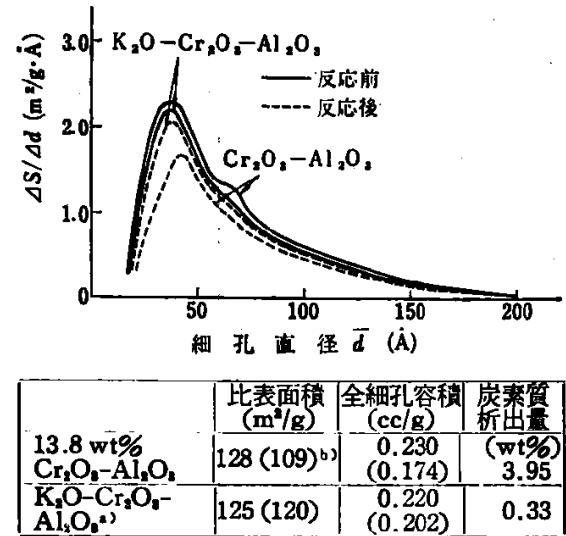

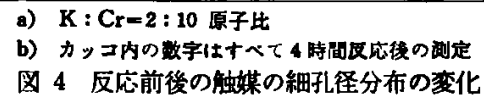

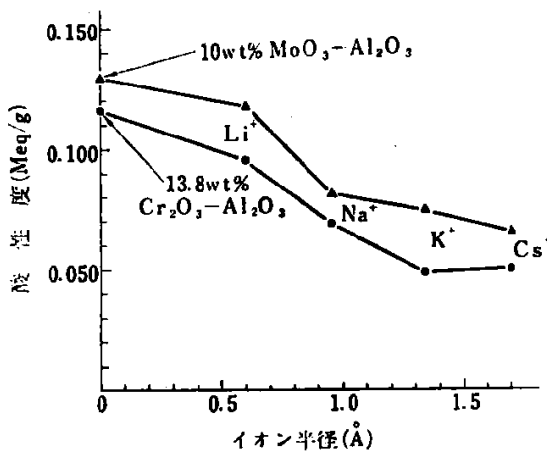

图 5 フルカリ金属の添加による酸性度の变化 （Crまたは Mo 10 原子に対して原子比添加）
順序は $\mathrm{Li}^{+}<\mathrm{Na}^{+}<\mathrm{Cs}^{+}<\mathrm{K}^{+} ; \mathrm{Mg}^{++}<\mathrm{Ba}^{++}<\mathrm{Ca}^{++}$であった。

3.3 モリブテナーアルミナ媒に対するアルカリおよびアル カリ土類の添加勃果

表 5 に示すごとくモリブデナーナルミナ触媒はりロミアーアル ミナよりも担持量が少ないにひかかわらず酸性度が大きいが， これは $\mathrm{MoO}_{2}$ (测定条件下では $\mathrm{Mo}$ は 4 価になっていると考 える）のほうが $\mathrm{Cr}_{2} \mathrm{O}_{3}$ よりも酸性度が大きいことに基づくも のであろう。アルカリおよびアルカリ土類の添加奻果はクロミ アーアルミナの場合に類似するが，図 6 および図 7 に示すごと くモリブデナの場合にはカリウムの添加とともにほぼ直線的に 酸性度が減少し，それに伴い炭素質析出量が減少して芳香族収 率，選択率は向上する。また各種アルカリの添加は図5に示す

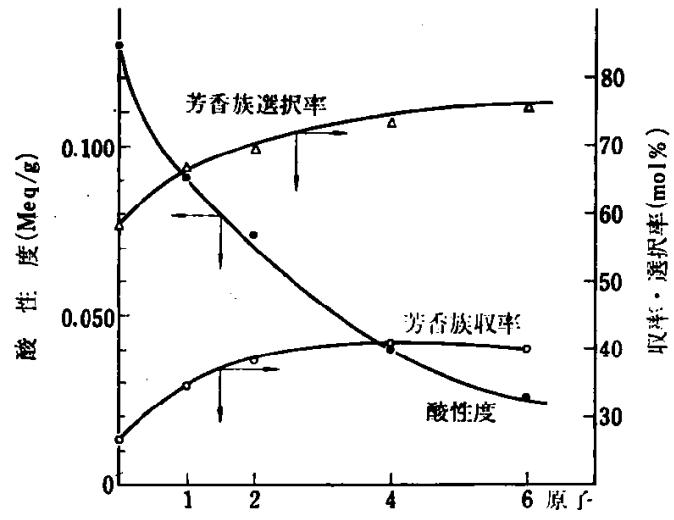

カリウム㴡加量(Mo 10 原子に対して)

图 6 モリブデナーナルミナ蜰媒に対するカリウムの添加作用

\begin{tabular}{|c|c|c|c|c|c|c|c|c|}
\hline 媒"' & 酸性/度 & $\begin{array}{c}\text { 对原料液收事 } \\
(\text { wt } \%)\end{array}$ & $\begin{array}{r}\text { 液中芳香 } \\
\text { (wt } 5 \\
\end{array}$ & 聟有量 & $\begin{array}{c}\text { 全芳香族収审 } \\
\text { (mol\%) }\end{array}$ & $\begin{array}{l}\text { 全芳香族選択事 } \\
\text { (mol\%) }\end{array}$ & $\mid \begin{array}{c}\text { 对原料炭素兴析出量 } \\
\text { (wt\%) }\end{array}$ & $\begin{array}{l}\text { 生成ガス量 } \\
l_{\text {NTP }}\left(\mathrm{H}_{\mathbf{2}} \%\right)\end{array}$ \\
\hline $\begin{array}{r}10 \mathrm{wt} / \% \\
\mathrm{Mo}_{4} \mathrm{O}-\mathrm{Al}_{2} \mathrm{O}_{4}\end{array}$ & 0.130 & 82.5 & $\begin{array}{r}1.5^{\mathrm{dj}} \\
26.6^{\mathrm{d})} \\
1.6^{\circ 3}\end{array}$ & 29.7 & 26.6 & 58.2 & 4.47 & $5.41(91.0)^{i)}$ \\
\hline $\begin{array}{l}(\mathrm{K}: \mathrm{Mo}=1,10)^{b)} \\
\mathrm{K}_{4} \mathrm{O}-\mathrm{MOO}_{2}-\mathrm{Al}_{3} \mathrm{O}_{2}\end{array}$ & 0.093 & 82.0 & $\begin{array}{r}1.9 \\
34.9 \\
1.4 \\
\end{array}$ & 38.2 & 34.2 & 66.4 & 3.24 & $5.65(94.7)$ \\
\hline $\mathrm{K}_{2} \mathrm{O}^{(\mathrm{K}: \mathrm{Mo}=2: 10)}$ & 0.074 & 82.9 & $\begin{array}{r}2.5 \\
38.0 \\
1.7 \\
\end{array}$ & 42.2 & 38.3 & 69.7 & 2.09 & $5.95(93.5)$ \\
\hline $\mathrm{K}_{2} \mathrm{O}^{(\mathrm{K}: \mathrm{Mo}=4: 10)}$ & 0.040 & 83.6 & $\begin{array}{r}2.9 \\
40.3 \\
1.1 \\
\end{array}$ & 44.3 & 40.6 & 73.1 & 1.18 & $5.82(93.6)$ \\
\hline $\mathrm{K}_{2} \mathrm{O}^{(\mathrm{K}: \mathrm{Mo}=6: 10)}$ & 0.026 & 86.6 & $\begin{array}{r}3.3 \\
37.9 \\
0.7 \\
\end{array}$ & 41.9 & 39.9 & 75.8 & 0.58 & $5.68(94.2)$ \\
\hline $\mathrm{Li}_{2}(\mathrm{Oi}: M o=2: 10)$ & 0.118 & 84.0 & $\begin{array}{r}1.9 \\
30.0 \\
0.9 \\
\end{array}$ & 32.8 & 30.1 & 63.7 & 4.27 & $5.45(92.1)$ \\
\hline$\underset{\mathrm{Na}_{3} \mathrm{O}-}{(\mathrm{Na}: \mathrm{Mo}=2: 10)}$ & 0.081 & 81.3 & $\begin{array}{r}2.7 \\
38.4 \\
1.9\end{array}$ & 43.0 & 38.2 & 67.1 & 2.74 & $5.92(92.0)$ \\
\hline $\mathrm{Cs}_{2} \mathrm{O}^{\left(\mathrm{Cs}_{s}: \mathrm{Mo}=2: 10\right)}$ & 0.066 & 82.9 & $\begin{array}{r}2.5 \\
40.5 \\
1.1\end{array}$ & 44.1 & 40.1 & 70.9 & 1.64 & $5.86(92.2)$ \\
\hline 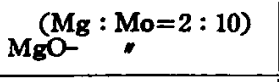 & 0.110 & 84.7 & $\begin{array}{r}1.8 \\
30.3 \\
1.6 \\
\end{array}$ & 33.7 & 31.1 & 64.8 & 4.41 & 5.38 \\
\hline $\mathrm{CaO}^{(\mathrm{Ca}: \mathrm{Mo}=2: 10)}$ & 0.103 & 82.2 & $\begin{array}{r}2.7 \\
37.2 \\
1.3 \\
\end{array}$ & 41.2 & 37.1 & 67.5 & 3.04 & 6.01 \\
\hline $\mathrm{BaO}^{(\mathrm{Ba}: \mathrm{Mo}=2: 10)}$ & 0.090 & 84.1 & $\begin{array}{r}2.2 \\
33.8 \\
1.5\end{array}$ & 37.5 & 34.4 & 68.5 & 2.91 & $5.30(92.1)$ \\
\hline
\end{tabular}

(口!.

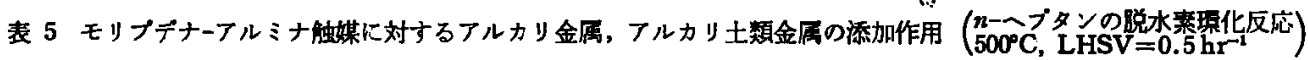

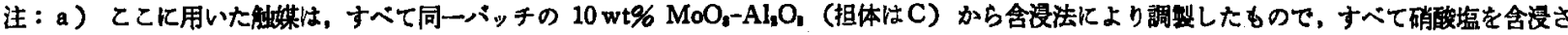
せ, $5000^{\circ} \mathrm{C}, 2$ 時間暁成した。
b) 原子比, c) ベンゼン,
d) トルエン, e) キシレン

f）生成ガス中の水素の vol\%. 


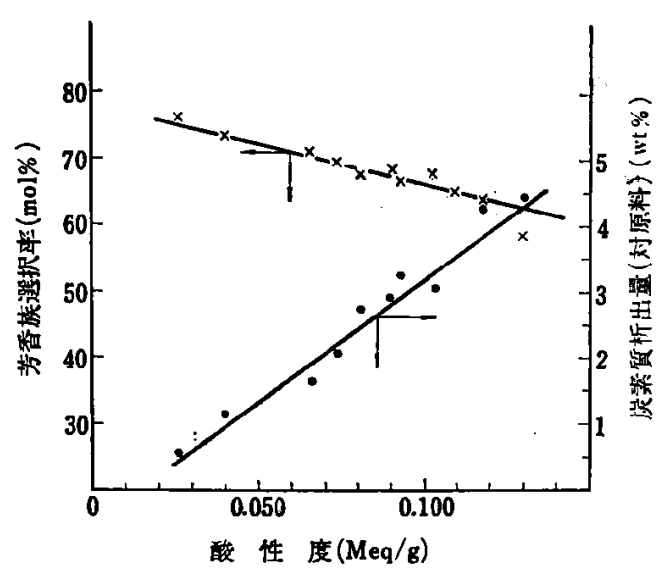

图 7 モリブデナーアルミナ系触媒の酸性度と芳香族化反応 （表 5 よりブロット）

ごとく, $\mathrm{Li}^{+}<\mathrm{Na}^{+}<\mathrm{K}^{+}<\mathrm{Cs}^{+}$の順にすなわちイオン半径の大 きくなるほど酸性度抑制効果が大となり，それに伴い炭素啠析 出量が娍少し芳香族化選択性は向上する。これは反応は異にす るが Danforth ${ }^{31)}$ のシリカーアルミナ蟹によるセタンのクラ ッキング活性に対ナるアルカリの抑制効果がイオン半径の大き さの順になるといら報告と一致している。アルカリ土類も同様 な効果を有し，その順序は $\mathrm{Mg}^{++}<\mathrm{Ca}^{++}<\mathrm{Ba}^{++}$とやはりイオ ン半径の順になっているが，その効果はアルカリの場合上りむ 小さい。またもりブデナーアルミナ触媒はクロミアーアルミナの 場合と異なり図3に示すごとくカリウムの添加の有無にかかわ らず経時活性上昇は見られない。

\section{4 锠括}

nーヘプタンの芳香族化反応の触媒およびこれに用いた担体 アルミナの酸性度をピリジンの気相吸着法により測定し,これ と芳香族化の選択性の関係について検討し次の結果を得た。

(1) 酸性度に差のある6種のアルミナにクロミアを担持さ せた触媒の酸性度は担体フルミナの酸性度の大きさの順序と同 ヒになる。またこれらの酸性度と $n$-ヘブタンの芳香族化選択 性，炭素質析出量などとの間に良い相関性がみられた。

(2) クロミアーアルミナおよびモリブデナーアルミナ触媒に 対するアルカリおよびアルカリ土類の添加効果を検討した。こ れらの添加によりクロミフ（あるいはモリブデナ）および担体 アルミナの双方に存在する酸性点が被毒され, 酸性点上で起る 副反応（主として炭素質析出）が抑制されることにより芳香族 化の選択性を向上させた。添加効果はアルカリのほうが大き く，またイオン半径の大きなるのほど大きい傾向がある。

終りに本研究を行な5にあたり，種々指導を賜わるとともに 発表を許可された会杜上司の方々，ならびに実験に熱心なる協 カをいただいた田尻忠士，苻川規育，大田正昭の三君に厚く謝
意を表する。

\section{文}

1）芳香族化反応の綕説としては

a) Steiner, A.H., "Catalytic Cyclization and Aromatization of Hydrocarbons", in Catalysis, Vol. IV, 529-560, edited by Emmett, P.H. (1956) Reinhold, New York. b) Ciapetta, F.G., Dobres, R.M., Baker, R.W., "Catalytic Reforming of Pure Hydrocarbons and Petroleum Naphthas", in Catalysis, Vol.VI, 495-692 (1958).

c) Hansch, C., Chem. Revs., 353 (1953).

2) Selwood, P.W., Eischens, R.P., J. Am. Chem. Soc., 69. 1590 (1947); 69, 2698 (1947); 70, 2271 (1948).

3) Cossee, P., Van Reijen, L.L., Proceedings from the Second International Congress in Catalysis, Paris, 1960, pp. 1679, Technip, Paris, 1961.

4) Owen, J.R., J. Am. Chem. Soc., 69, 2559 (1947).

5) Weisz, P.B., Prater, C.D., Rittenhouse, K.D., J. Chem. Phys., 21, 2236 (1953);

6) Voltz, S.E., Weller, S., J. Am. Chem. Soc., 75, 5227 (1953); 78, 4701 (1954).

7) Gremillion, A.F., Knox, W.R., J. Calalysis, 1, 216 (1962).

8) Russel, A.S., Stokes, J.J., Ind. Eng. Chem., 38, 1071 (1946); 40, 520 (1948).

9) Webb, G.M., Smith, M.A., Ehrhardt, R.P., Petrol. Processing, 1, 835 (1947),

10）斯波忠夫。池辺清，尾崎卒，化学、增刊第 2 号， 82,(1957)化学 同人社.

11) Archibald, R.C., Greensfelder, B.S., Ind. Eng. Chem., 37, 356 (1945).

12) Rozengart, M.I., Kazanskii, B.A., Doklady Akad. Nauk, 119. 716 (1958).

13) Shuikin, N.I. et al., lzvest. Akad. Nauk, Otdel. Khim. Nauk, 567 (1955).

14) Rhoobia, S., Steiner, R.O., Fr, 1,333,360 (1963).

15) Voltz, S.E., Weller, S.W., J. Phys. Chem., 59, 569 (1955).

16) Voltz, S.E., Hirschler, A.E., Smith, A., J. Phys. Chem., B4, 1594 (1960).

17) Bridges, T.M., Rymer, G.T., MacIver, D.S., J. Phys. Chem., 66, 871 (1962).

18）田部浩三, 触某工学請座 4 巻, 161 (1964) 地人書館.

19）服部英, 石油誌。 7, (10), 694 (1964).

20) Mills, G.A., Boedeker, E.R., Oblad, A.G., J. Am. Chem. Soc., 72, 1554 (1950).

21) 中野文椎, 分析機器, 2, (7), 30 (1964).

22) Nelsen, F.M., Eggertsen, F.T., Anal. Chem., 30, 1387 (1958).

23) Chem. Eng. News, Jan. 29, Part 1, 40 (1962).

24) Barrett, E.P., Joyner, L.G., Halenda, P.P., J. Am. Chem. Soc., 73, 373 (1951).

25）鈴村基, 吉田浩, 富田裕, 富士原厇。石油誌, 8，(4), 249 (1965).

26) Pines, H., Haag, W.O., J. Am. Chem. Soc., 82. 2471 (1960).

27) Pines, H., Chen, C.T., J. Am. Chem. Soc., 82, 3562 (1960).

28) Pines, H., Benoy, G., J. Am. Chem. Soc., 82, 2483 (1960).

29) Webb, A.N., Ind. Eng. Chem., 49, 261 (1957).

30) Trambouze, Y., Compt. rend., 238, 1261 (1953).

31) Danforth, J.D., J. Phys. Chem., 58, 1030 (1954). 